\title{
PERSPEKTIF E-LEARNING DOSEN PROGRAM STUDI SISTEM INFROMASI UNIPMA
}

\author{
Dimas setiawan \\ Universitas PGRI Madiun \\ Jurusan Sistem Informasi, Fakultas Teknik, UNIPMA, Madiun \\ e-mail: dimas.setiawan@unipma.ac.id
}

\begin{abstract}
Abstrak - Penerapan lingkungan pendidikan berbasis teknologi bisa dilakukan dengan berbagai cara, salah satunya dengan memanfaatkan E-learning. Pembahasan E-learning bukanlah hal yang baru di kalangan sivitas akademik perguruan tinggi. E-learning berevolusi cukup cepat dan membawa dampak dimana E-learning saat ini terkesan bervariasi dan memiliki cakupan yang cukup luas. Sehingga muncul permasalahan mengenai perbedaan cara pandang terhadap E-learning. Untuk mengatasi hal tersebut diperlukan sebuah penelitian yang membahas mengenai prespektif E-learning. Analisa prespektif ini dilakukan untuk mendapatkan sebuah informasi tentang konsep E-learning bagi dosen program studi sistem informasi UNIPMA, yang nantinya di masa depan dapat dijadikan sebagai acuan untuk dilakukan sebuah evaluasi atau dijadikan alat bantu untuk pengambilan sebuah kebijakan di program studi sistem informasi terkait pengimplementasianE-learning.
\end{abstract}

Kata kunci-E-Learning

\section{Pendahuluan}

Universitas PGRI Madiun (UNIPMA) merupakan perguruan tinggi swasta yang diresmikan pada tanggal 3 januari 2017 dan memiliki 6 progam studi baru, salah satunya adalah program studi sistem informasi. Sebagai salah satu program studi yang bergerak di bidang teknologi dan informasi, sudah sepatutnya mampu mengimplementasikan lingkungan pendidikan berbasis teknologi. Dimana karateristik dari trend teknologi pendidikan saat ini pada umumnya menggunakan teknologi pembelajaran berbasis Online, mobile dan multimedia.[1].

Penerapan lingkungan pendidikan berbasis teknologi bisa dilakukan dengan berbagai cara, salah satunya dengan pemanfaatan E-learning. Pembahasan E-learning bukanlah sesuatu hal yang baru di kalangan sivitas akademik perguruan tinggi, termasuk di program studi sistem informasi UNIPMA.[2]

Pada awalnya E-learning sendiri merupakan kegiatan pembelajaran konvensional yang dituangkan kedalam format digital dengan memanfaatkan teknologi komputer dan internet sebagai media \& sumber ajar .
Namun E-learning sendiri berevolusi dan bekembang cukup cepat sehingga muncul istilah seperti Mobile learning yang merupakan bagian dari E-learning itu sendiri. Mobile learning merupakan bagian dari E-learning, yang membedakan disini adalah penggunaan media ajarnya, dimana dalam M-learning lebih menggunakan media yang bersifat mobility device [1]

Hal ini membawa dampak dimana E-learning saat ini terkesan bervariasi dan memiliki cakupan yang cukup luas. Sehingga muncul sebuah permasalahan dimana masing-masing dosen memiliki cara pandang tersendiri mengenai $E$ learning. Sebagai contoh adanya perbedaan pendapat tentang penggunaan sosial media whatsApp sebagai E-learning. permasalahan perbedaan pendapat dan cara pandang seperti ini apabila tidak segera diatasi maka kedepannya akan membawa dampak kurang baik bagi pengembangan dan pelaksanaan E-learning bagi program studi sistem informasi.

Maka dari itu untuk mengatasi permasalahan tersebut diperlukan sebuah penelitan yang berfungsi untuk menganalisa pemahaman $E$ learning bagi dosen program studi sistem informasi UNIPMA. analisa pemahamanini 
dilakukan untuk mendapatkan sebuah informasi tentang konsep E-learning bagi dosen program studi sistem informasi UNIPMA, yang nantinya dapat dijadikan sebagai acuan untuk dilakukan sebuah evaluasi atau dijadikan alat bantu untuk pengambilan sebuah kebijakan di program studi sistem informasi terkait pengimplementasian $E$ learning.

\section{LANDASAN TEORI}

Pendidikan berbasis teknologi merupakan sebuah kegiatan dimana didalamnya terdapat peserta didik dan pendidik yang berada dalam sebuah lingkungan belajar mengadakan kegiatan pembelajaran dimana teknologi digunakan sebagai alat bantu untuk membantu proses berlangsungnya kegiatan pembelajaran. [1]

Teknologi pembelajaran "Memfokuskan pada proses bagaimana teknologi perangkat lunak (software) dan perangkat keras (hardware) digunakan untuk mengkomunikasikan pengetahuan, keterampilan, atau sikap kepada pembelajar, sehingga pembelajar mengalami perubahan perilaku sebagaimana yang diharapkan".[]]

E-learning merupakan kegiatan pembelajaran konvensional yang dituangkan kedalam format digital dengan memanfaatkan teknologi komputer dan internet sebagai media \& sumber ajar. [1]

Rose menyebutkan bahwa ada dua macam model utama penyampaian dalam ELearning yaitu synchronous dan asynchronous. Dalam penyampaian synchronous, peserta didik dan pendidik bertemu ditentukan oleh waktu untuk melakukan proses pembelajaran. Dalam penyampaian asynchronous, peserta didik menggunakan bahan materi yang tersedia melalui website yang cukup lengkap untuk digunakan setiap waktu. Sehingga memungkinkan peserta didik untuk mengakses materi sesuaikebutuhan.[4]

Menurut Dewi dkk Karakteristik E-learning ini antara lain adalah:

a. Memanfaatkan jasa teknologi elektronik. dimana Guru dan siswa, siswa dan sesama siswaataugurudansesamagurudapat berkomunikasi dengan relatif mudah tanpa dibatasi oleh hal-hal yang bersifat protokoler.

b. Memanfaatkan keunggulan komputer (digital media dan computernetworks)

c. Menggunakan bahan ajar bersifat mandiri (self learning materials) disimpan di komputer sehingga dapat diakses oleh guru dan siswa kapan saja dan di mana saja bila yang bersangkutanmemerlukannya

d. Memanfaatkan jadwal pembelajaran, kurikulum, hasil kemajuan belajar dan hal-hal yang berkaitan dengan administrasi pendidikan dapat dilihat setiap saat di computer. []

Mobile learning merupakan bagian dari Elearning, yang membedakan disini adalah penggunaan media ajarnya, dimana dalam $M$ learning lebih menggunakan media yang bersifat mobility device (setiawan 2017)lebih lanjut tentang mobile learning "Mobile learning combines E-learning and mobile computing ... but quality M-learning can only be delivered with an awareness of the special limitations and benefits of mobile devices". [6]

\section{METODE}

Metode penelitian yang digunakan di dalam penelitian ini , diantaranya adalah :

a. Observasi

Observasi digunakan untuk mendapatkan data mengenai prespektif e-learning menggunakan kuisioner dengan skala likert yang diberikan kepada responden.

b. Studipustaka

Data dan informasi yang diperoleh melalui studi pustaka bersifat sekunder yaitu data yang diperoleh melalui studi literature, jurnal, bukubuku dan tulisan ilmiah tentang e-learning.

sedangkan tahapan dari penelitian yang dilakukan adalah sebagai berikut:

a. Studi pustaka mengenai karateristik ,trend dan fenomena di lingkungan pendidikan terkait tentangE-learning.

b. Setelah mendapatkan data terkait karateristik E-learning langkah selanjutnya adalah penyusunankuisioner.

c. Kuisioner disebar keresponden. 
d. Data dari kuisioner diolah dan dianalisa menjadi informasi berupa hasil penelitian dankesimpulan.

Analisa mengenai prespektif E-learning dilakukan dengan melakukan penyebaran kuisioner kepada dosen program studisistem informasi yang berstatus aktifmengajar.

\section{HASIL}

Hasil dari studi pustaka disusun sebuah kuisioner dengan poin pertanyaan sebanyak 13 butir, dimana butir pertama menanyakan tentang definisi $E$ learning, butir ke 2-5 terkait dengan karakteristik E-learning, butir ke 6-7 terkait dengan Mobile learning sebagai bagian dari E-learning, butir-8 terkait penggunaan sosial media sebagai $E$ learning, butir 9-10 terkait dengan pengembangan E-learning, butir 11 terkait nilai penting $E$ learning bagi pengguna, butir 12-13 terkait dengan kelebihan dan kelemahan E-learning.

\begin{tabular}{|c|l|}
\hline \multicolumn{3}{|c|}{ "Prespektif" E-learning dosen program studi } \\
sistem informasi
\end{tabular}

\begin{tabular}{|c|l|}
\hline & $\begin{array}{l}\text { hal yang berkaitan dengan administrasi } \\
\text { pendidikan yang dapat dilihat setiap saat di } \\
\text { komputer. }\end{array}$ \\
\hline 6 & $\begin{array}{l}\text { Mobile learning merupakan bagian dari E- } \\
\text { learning, yang membedakan disini adalah } \\
\text { penggunaan media ajarnya, dimana dalam } \\
\text { M-learning lebih menggunakan media yang } \\
\text { bersifat mobility device }\end{array}$ \\
\hline 7 & $\begin{array}{l}\text { Karakteristik Mobile Learning = Electronic } \\
\text { Learning, dikarenakan Mobile learning } \\
\text { merupakan bagian dari E learning yang } \\
\text { membedakan hanyalah device yang } \\
\text { digunakan }\end{array}$ \\
\hline 8 & $\begin{array}{l}\text { Sosial Media digunakan sebagai E learning } \\
\text { maupun Mobile Learning (Whatss app, FB, } \\
\text { Instagram, dsb) }\end{array}$ \\
\hline 9 & $\begin{array}{l}\text { Pengembangan E-learning yang optimal } \\
\text { perlu memperhatikan proses Knowledge } \\
\text { Management (manajemen pengetahuan)dan } \\
\text { Knowledge transfer (transfer pengetahuan) }\end{array}$ \\
\hline 10 & $\begin{array}{l}\text { Pengembangan dapat } \\
\text { dikembangkan secara optimal dengan } \\
\text { menggunakan LMS (learningmanagement } \\
\text { System) }\end{array}$ \\
\hline 11 & $\begin{array}{l}\text { E-learning akan dimanfaatkan atau tidak } \\
\text { sangat tergantung bagaimana pengguna } \\
\text { memandang atau menilai E-learning tersebut. }\end{array}$ \\
\hline 12 & $\begin{array}{l}\text { kelebihan E-leraning salah satunya adalah } \\
\text { Akses materi Komunikasi \& Tes / uji } \\
\text { kompetensi yang bisa dilakukan kapanpun \& } \\
\text { dimanapun. }\end{array}$ \\
\hline 13 & $\begin{array}{l}\text { Kekurangan E-learning adalah Kurangnya } \\
\text { interaksi antara guru dan siswa atau bahkan } \\
\text { antar siswa itu sendiri. Kurangnya interaksi } \\
\text { ini bisa memperlambat terbentuknyavalue } \\
\text { dalam proses belajar dan mengajar }\end{array}$ \\
\hline
\end{tabular}

Tabel.1 Kuisioner "Prespektif” E-learning dosen program studi sistem informasi

Hasil dari penyebaran kuisioner dari 6 responden dosen didapat prosentase $50 \%$ setuju \& $50 \%$ sangat setuju bahwa E-learning merupakan model kegiatan pembelajaran konvensional yang dituangkan kedalam format digital dengan memanfaatkan teknologi komputer \& internet sebagi media \& sumber ajar. 


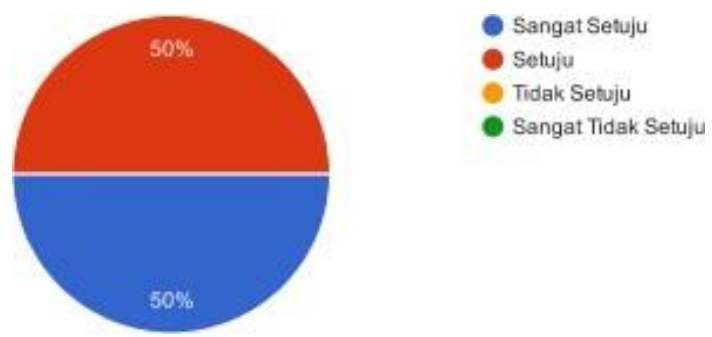

Gambar 1. Hasil prosentase tentang definisi E-learning

Prosentase $50 \%$ setuju dan 50\% sangat setuju bahwa karateristik E-learning yaitu memanfaatkan jasa teknologi elektronik. Dimana anatara guru dan siswa, siswa dan sesama siswa atau guru dan sesama guru dapat berkomunikasi dengan relatif mudah tanpa dibatasi oleh hal-hal yang bersifat protokoler.
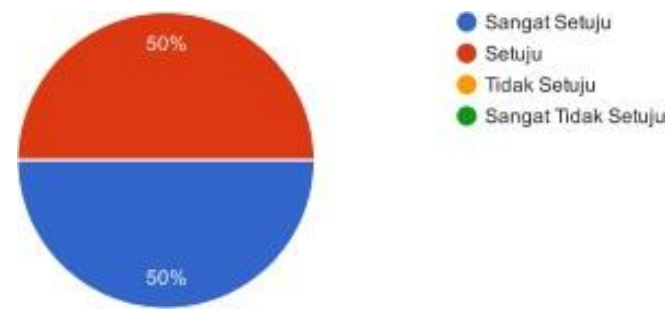

Gambar 2. hasil prosentase karateristik E-learning memiliki pemanfaatan jasa teknologielektronik.

Prosentase $83,3 \%$ setuju dan $16,7 \%$ sangat setuju bahwa karakteristik E-learning yaitu memanfaatkan keunggulan teknologi komputer (digital media dan computer networks) \&internet.
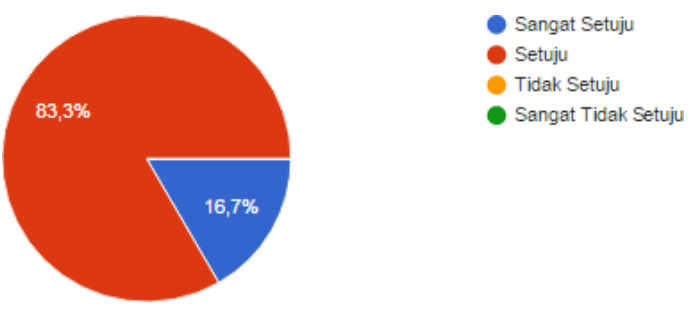

Gambar 3. Hasil prosentase karakteristik $E$ learning memanfaatkan keunggulan digitalmedia $\&$ computer networks

Prosentase $50 \%$ setuju dan $50 \%$ sangat setuju untuk karakteristik E-learning yaitu menggunakan bahan ajar bersifat mandiri dan disimpan disebuah database sehingga dapat diakses oleh guru maupun siswa kapan saja dan dimana saja bila yang bersangkutan memerlukan.

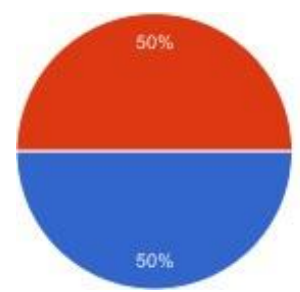

- Sangat Setuju

- Setuju

Tidak Setuju

- Sangat Tidak Setuju

Gambar 4. Hasil prosentase karakteristik $E$ learning yang menggunakan database untuk penyimpanan materi

Prosentase 83,3 \% setuju dan 16,7 \% tidak setuju untuk karakteristik E-learning yang memanfaatkan jadwal pembelajaran, kurikulum, hasil kemajuan belajar dan hal-hal yag berkaitan dengan administrasi pendidikan yang dapat dilihat setiap saat dikomputer.
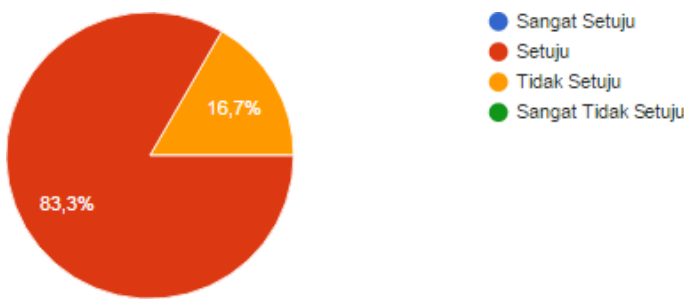

Gambar 5. Hasil prosentase karakteristik $E$ learning untuk pemanfaatan jadwal pembelajaran, kurikulum,hasil kemajuan belajar, dan administrasi pendidikan.

Prosentase $50 \%$ setuju dan $50 \%$ sangat setuju bahwa Mobile learning merupakan bagian dari $E$ learning.

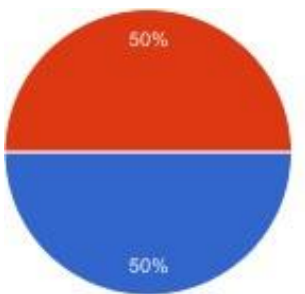

- Sangat Setuju

- Setuju

Tidak Setuju

Sangat Tidak Setuju

Gambar 6. Hasil prosentase M-learning merupakan bagian dari E-learning.

Prosentase $83,3 \%$ setuju dan $16,7 \%$ sangat setuju bahwa karakteristik M-learning sama dengan karakteristik E-learning.. 


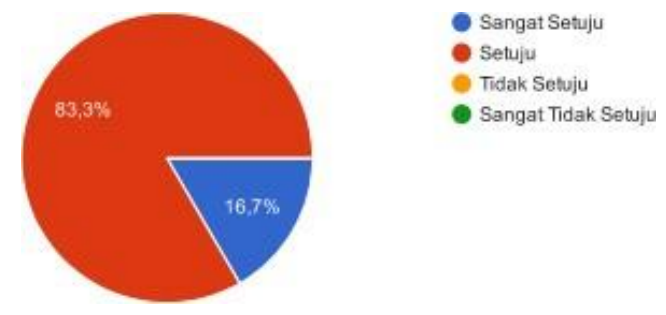

Gambar 7. Hasil prosentase karakteristik $M$ learning sama dengan karakteristik E-learning.

Prosentase $50 \%$ setuju dan $50 \%$ tidak setuju untuk poin pernyataan sosial media digunakan sebagai E-learning .

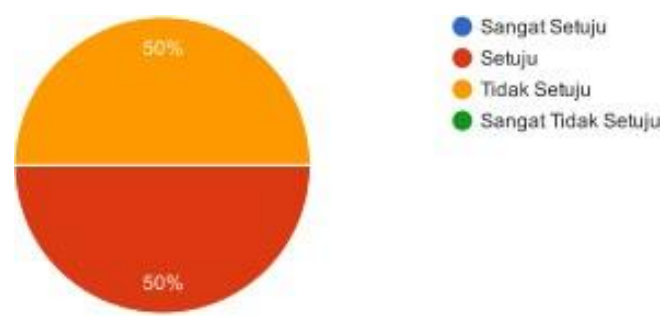

Gambar 8. Hasil prosentase sosial media digunakan sebagai E-learning.

Prosentase $66,7 \%$ setuju dan $33,3 \%$ sangat setuju untuk pengoptimalan E-learning perlu memperhatikan proses knowledge management (manajemen pengetahuan) dan knowledge transfer (transfer pengetahuan).
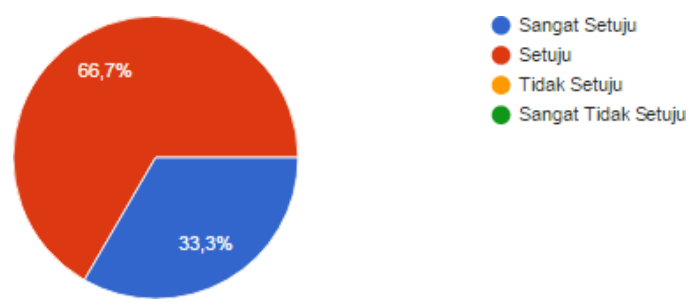

Gambar 9. Hasil prosentase pengoptimalan $e$ learning memperhatikan knowledge manajemen \& knowledge transfer.

Prosentase $66,7 \%$ setuju dan $33,3 \%$ sangat setuju untuk pengoptimalan E-learning dapat menggunakan LMS (learning Management System).

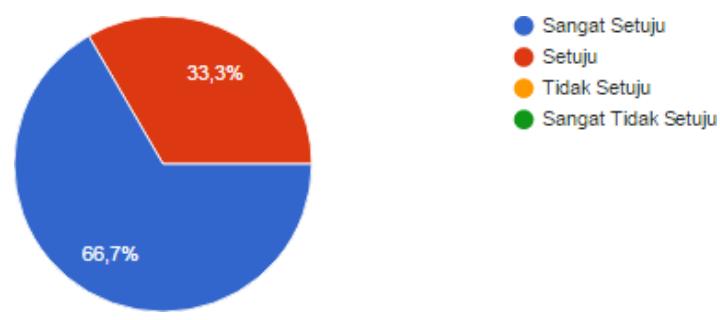

Gambar 10. Hasil prosentase pengembangan $e$ learning dapat dikembangkan dengan LMS.

Prosentase $50 \%$ setuju dan $50 \%$ sangat setuju E-learning dimanfaatkan atau tidak sangat bergantung pada bagaimana pengguna memandang atau menilai E-learning.

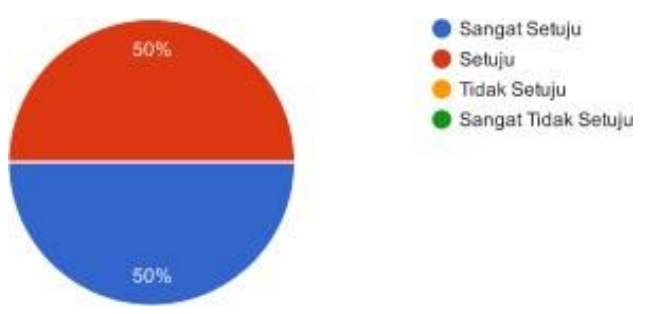

Gambar 11. Hasil prosentase untuk pernyataan $E$ learning bergantung pada bagaimana pengguna menilai E-learning.

Prosentase $50 \%$ setuju \& $50 \%$ sangat setuju bahwa kelebihan E-learning adalah akses materi, komunikasi, dan uji kompetensi yang bisa dilakukan kapanpun dan dimanapun.

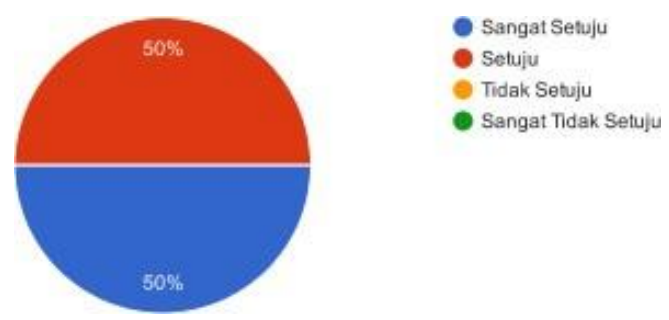

Gambar 12. Hasil prosentase untuk kelebihan E learning adalah akses materi, komunikasi, \& uji kompetensi bisa dilakukan kapanpun \& dimanapun.

Prosentase $66,7 \%$ setuju, $16,7 \%$ sangat setuju , dan $16,7 \%$ tidak setuju bahwa kelemahan yang ada di E-learning adalah kurangnyainteraksi. 
DAFTAR PUSTAKA

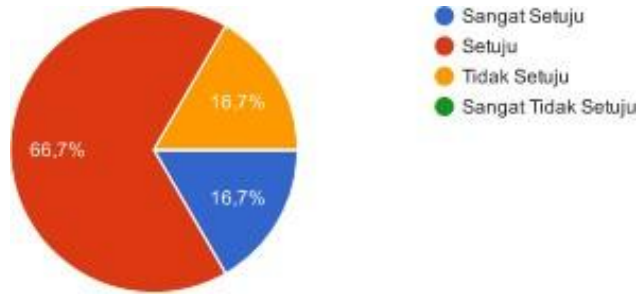

Gambar 13. Hasil prosentase untuk kelemahan E-learning adalah kurangnya interaksi.

\section{KESIMPULAN}

Secara umum E-learning bagi dosen program studi sistem infromasi merupakan sebuah kegiatan pembelajaran konvensional yang dituangkan ke format digital dengan memanfaatkan teknologi komputer dan internet sebagai media dan sumber ajarnya, yang didalamnya memiliki beberapa karakteristik tertentu.

Pengembangan E-learning perlu memperhatikan aspek knowledge transfer \&knowledge management dan dapat dioptimalkan dengan beberapa metode salah satunya LMS (Learning managementsystem).

Mobile learning merupakan bagian dari Electronic learning. M-learning memiliki kesamaan karaktersitik dengan E-learning dimana pembedanya hanyalah device yang bersifat mobility.

Bagi dosen program studi sistem informasi sosial media tidak dapat $100 \%$ dapat disebut sebagai E-learning, karena sifatnya lebih mengarah ke support learning atau pendukungbelajar.

E-learning sendiri memiliki kelebihan dan kekurangan, untuk kelebihan dari E-learning diantaranya akses materi, komunikasi, \& uji kompetensi bisa dilakukan kapanpun dan dimanapun sedangkan kelemahan yang ada pada elearning itu sendiri adalah kurang bagusnya interaksi antara pengajar dan siswa ajar.

E-learning dapat dimanfaatkan secara optimal atau tidak sangat bergantung pada bagaimana pengguna memandang atau menilai E-learning
[1] Setiawan. Dimas, Asnawi. Noordin, and Mumtahana. Hani. Atun, "EVALUATION OF STYLE-TEACHING LECTURERS INFORMATICS ENGINEERING STUDY PROGRAM UNIPMA IN TREND EDUCATION BASED ON TECHNOLOGY", in Proceeding - 2017 International Conference on Education and Science (ICONS), 2017, pp. 1168-1173.

[2] Silahudin, "Penerapan E-LEARNING dalam Inovasi Pendidikan," CIRCUIT, vol. I, pp. 48-57, Juli 2015.

[3] Mukminan, "Teknologi Pendidikan Untuk Peningkatan Kualitas Pembelajaran," in Seminar Nasional Teknologi Pendidikan, Pontianak, 2012, pp. 1-12.

[4] Nugraha I Kadek Agus Erta, Agustini Ketut, and Sindu I Gede Partha, "Analisis Pemanfaatan E-Learning Sebagai Knowledge Management Dalam Mendukung Proses Pembelajaran Di Jurusan Pendidikan Teknik Informatika Undiksha," KARMAPATI, vol. VI, no. 1, 2017.

[5] Indrawan Irjus, "Meningkatkan Mutu Pendidikan Melalui Metode E-Learning," Jurnal AL-AFKAR, vol. III, pp. 6983, Oktober 2014.

[6] Behera Santosh Kumar, "E- AND M-LEARNING: A COMPARATIVE STUDY," International Journal on 